\title{
Finishing lambs on a chicory-plantain mixture or a temperate grass- based pasture: live weight gain and gastrointestinal parasitism
}

\author{
Daniel Alomar', Paula Ruiz², Oscar Balocchi¹, Gastón Valenzuela ${ }^{3}$, and \\ Daneska Goic ${ }^{1}$ \\ ${ }^{1}$ Universidad Austral de Chile, Facultad de Ciencias Agrarias, Instituto Producción Animal. Valdivia, \\ 5090000, Chile. \\ ${ }^{2}$ Universidad Austral de Chile, Facultad de Ciencias Agrarias, Escuela de Graduados. Valdivia, 5090000, Chile \\ ${ }^{3}$ Universidad Católica de Temuco, Facultad de Recursos Naturales, Unidad de Parasitología. Temuco, \\ 4780000, Chile
}

\begin{abstract}
D. Alomar, P. Ruiz, O. Balocchi, G. Valenzuela, and D. Goic. 2018. Finishing lambs on a chicoryplantain mixture or a temperate grass-based pasture: live weight gain and gastrointestinal parasitism. Cien. Inv. Agr. 45(1): 11-20. Improved plantain (Plantago lanceolata L.) and chicory (Cichorium intybus L.) are attractive forage species for finishing lambs and contain compounds that might protect sheep from gastrointestinal nematodes. This study compared the live weight gain and parasite burden of weaned lambs finished on a plantain-chicory mix (Pl-C) or a permanent grassbased pasture (PP) and treated with or without an endectocide. From mid-November, weaned lambs $(\mathrm{n}=72$, average live weight $32 \mathrm{~kg}$ ) were distributed into three paddocks per sward type for $30 \mathrm{~d}$. Half of the lambs were initially treated with ivermectin. Fecal egg counts (FEC), larvae genera and the presence of infective larvae (L3) in pastures were evaluated. No differences $(\mathrm{P}>0.05)$ were obtained between the pastures for the initial (ca. $80 \mathrm{epg}$ ) or final FEC (322 epg) or type of eggs (Strongylidor Nematodirus-type). Ivermectin treatment reduced ( $\mathrm{P}<0.01)$ the total FEC (482 vs. $158 \mathrm{epg}$ ) and the Strongylid- (418 vs. $148 \mathrm{epg}$ ) and Nematodirus-type eggs (64 vs. 9 epg). No significant effects $(\mathrm{P}>0.05)$ of pasture type or anthelmintic treatment and no interactions were detected on the cultured larvae genera, except for Cooperia, which decreased with the anthelmintic treatment. By day 30, the number of L3 recovered from the pastures increased $(\mathrm{P}<0.05)$ in the PP $\left(62\right.$ to $280 \mathrm{~L}^{3} \mathrm{~kg}^{-1}$ $\mathrm{DM}$ ), while the number was unchanged $(\mathrm{P}>0.05)$ in the $\mathrm{Pl}-\mathrm{C}$ (average $\left.63 \mathrm{~L}^{\mathrm{kg}} \mathrm{kg}^{-1} \mathrm{DM}\right)$. The parasite load estimated by the FEC reached low infection levels ( $<400 \mathrm{epg}$ ), preventing clinical signs. The live weight gain of lambs was similar $(\mathrm{P}>0.05)$ among treatments (average $173 \mathrm{~g} \mathrm{~d}^{-1}$ ), reflecting an adequate nutritional quality of both pastures and a moderate parasitism status of the lambs.
\end{abstract}

Key words: Herb swards, infective larvae, nematodes, sheep.

\section{Introduction}

In humid temperate zones, permanent grassbased pastures are the basis of sheep production systems. Such systems are exposed to frequent

Received Sep 25, 2017. Accepted Mar 13, 2018.

Corresponding author: dalomar@uach.cl late spring and summer rainfall deficits, affecting pasture growth and animal performance. Improved cultivars of herbs such as plantain and chicory appear attractive for finishing lambs, since they have good nutritional quality and are more tolerant to water stress compared to most grasses. Parasitic diseases caused by gastrointestinal nematodes (GIN) are responsible for 
important economic losses in lamb production systems based on pastures. Traditionally, the use of anthelmintics has been the main method to control the worm burden in lambs. However, resistance developed by GIN to common anthelmintics (Toro et al., 2014) has forced the pharmaceutical industry to develop stronger drugs. Sheep producers in turn have been compelled to intensify their control strategies by adopting and rotating new drugs and increasing the deworming frequency. In recent decades, however, a holistic approach has emerged to help cope with sheep parasitism, involving different anthelmintic treatments and grazing management strategies. These treatments and strategies may result in better parasite control at more reasonable costs although not necessarily eliminating anthelmintic resistance.

Secondary metabolites from a number of plants show anthelmintic effects attributed either to an increased immune status of the animals resulting from improved protein nutrition or a direct deleterious effect on nematodes (Githiori et al., 2006). Among such plants, plantain (Plantago lanceolata) and chicory (Cichorium intybus) are species of particular interest. Condensed tannins (plantain) and sesquiterpene lactones (chicory) are two groups of bioactive metabolites that have been reported to reduce nematode larval motility in vitro (Molan et al., 2003) and worm burdens in grazing lambs (Githiori et al., 2006). The action of tannins could be explained by their indirect effect on reducing the ruminal degradation of proteins and increasing amino acid absorption at the intestinal level (Waller and Thamsborg, 2004; Ramírez-Restrepo and Barry, 2005), as well as their direct deleterious effect on nematodes, by either damaging the larvae cuticle (Yoshihara et al., 2015) or by decreasing oviposition in the reproductive stage (Waller and Thamsborg, 2004). Sesquiterpene lactones have been shown to reduce egg hatchability and larval motility or feeding ability (Peña-Espinoza et al., 2015), which could explain the reduction in the establishment of incoming larvae.
Therefore, the use of these herb species could benefit sheep production systems by improving the availability of quality forage and maintaining a lower parasite burden, reducing the dependence on antiparasitic drugs and consequently helping to delay the development of the anthelmintic resistance commonly observed in systems with frequent drug usage. Although some previous research has been conducted in this area, it is important to gather information for locations where high winter rainfall and frequent summer droughts configure special environments in the context of global climatic change. The present work was carried out with the hypothesis that a chicory-plantain mixture could result in a lower parasitic load and hence a higher live weight gain in weaned lambs. Consequently, our objective was to evaluate the effects of the type of pasture (a mixture of plantain and chicory compared with a grass-based permanent pasture) and the application (or not) of an anthelmintic treatment on the live weight gain of weaned lambs, the load of gastrointestinal nematodes estimated through fecal egg counts (FEC), the larvae genera obtained from fecal cultures and the number of infective larvae in the experimental pastures (ILIP).

\section{Material and methods}

Two swards, one containing a mixture of herbs (Pl-C) and the other containing a permanent pasture (PP) with several species of grasses, were established in three paddocks of $1,500 \mathrm{~m}^{2}$ for each mixture in mid-March in an Andisol (Duric Hapludand) soil Series Valdivia with a silty loam texture located at the Agricultural Experimental Station (Santa Rosa farm) of Universidad Austral de Chile in Valdivia, Chile. For the Pl-C pasture species, cultivars and seed doses were as follows: plantain (Plantago lanceolata L., Tonic) $8.4 \mathrm{~kg}$ ha $^{-1}$ and chicory (Cichorium intybus L., Choice) $8.4 \mathrm{~kg} \mathrm{ha}^{-1}$. For the PP pasture, the respective species, cultivars and values were as follows: ryegrass (Lolium perenne L., Rohan) $8.6 \mathrm{~kg} \mathrm{ha}^{-1}$, bromegrass (Bromus valdivianus Phil., Poker) 
$11.52 \mathrm{~kg} \mathrm{ha}^{-1}$, tall fescue (Festuca arundinacea Screb., Kora) $8.64 \mathrm{~kg} \mathrm{ha}^{-1}$, cocksfoot (Dactylis glomerata L., Safin) $5.76 \mathrm{~kg} \mathrm{ha}^{-1}$, Yorkshire fog grass (Holcus lanatus L.) $2.88 \mathrm{~kg} \mathrm{ha}^{-1}$ and white clover (Trifolium repens L., Weka) $3.6 \mathrm{~kg} \mathrm{ha}^{-1}$.

In mid-August and early October, the paddocks were intensively grazed for three days by ewes and their lambs to control pasture growth and ensure that a population of infective larvae were present when the experimental period started in mid-November.

On November 14th, 72 Austral (Finnish Landrace $\mathrm{x}$ Romney) weaned lambs approximately four months old with an average live weight of 32 $\mathrm{kg}$ were randomly allocated to the trial, with 12 lambs for each paddock (36 per pasture type). All the lambs had been routinely dewormed in August, September and October with Rumiten ${ }^{\circledR}$ (fenbendazole and praziquantel). At the beginning of the trial, half of the animals $(n=6)$ in each plot were treated with ivermectin $1 \%$ at a dose of 0.2 $\mathrm{mg} \mathrm{kg}^{-1}$ body weight. The remaining six lambs were not dewormed. The lambs were strip grazed with electric fencing ( 2 to $4 \mathrm{~d}$ in each break, six breaks per paddock) and determined by sward height, with a goal of $10 \mathrm{~cm}$ and $7 \mathrm{~cm}$ for the Pl-C pasture for entering and exiting, respectively, and $8 \mathrm{~cm}$ and $5 \mathrm{~cm}$ for the PP pasture, respectively. At the end of the last break, the lambs returned to the first strip and so on, but in the last 4 to 6 $\mathrm{d}$, each complete paddock was made available, as the lack of rain resulted in a forage shortage, especially in the case of the PP pastures. All the lambs were housed at night for security reasons in separate pens, one per paddock, in a nearby barn. The trial lasted $30 \mathrm{~d}$ (i.e., was terminated by mid-December). All the lambs were weighed at the start and end of the experiment, in the morning, to compare the live weight gain between treatments. The pastures were sampled at days 8,15 and 30 from the start of the experiment to determine crude protein, metabolizable energy, neutral detergent fiber, acid detergent fiber and total ash.
Individual fecal samples were taken at the beginning and end of the trial (day 30). The fecal egg counts were determined by the McMaster procedure for quantifying total nematode eggs and separating Strongylid- and Nematodirus-type eggs. Pooled samples of feces (10 g per paddock) were used to determine nematode genera by larval culture. The procedure provides favorable environmental conditions (humidity, temperature, aeration) for egg hatching and larvae development to the L3 stage. The fecal material was placed in a widemouthed jar with sterilized water, covered with a loose Petri dish and placed in an incubation oven for $10 \mathrm{~d}$ at $18{ }^{\circ} \mathrm{C}$. At the end of this incubation period, the flask was inverted into the Petri dish, water was added to the dish border, and the system was left to settle. The larvae were recovered after four hours by extracting the liquid from the dish and transferring it to an assay tube, before being pipetted from the bottom of the tube to a slide and identified. The genera identification of L3 was performed by using the key of the Manual of Laboratory Techniques of Veterinary Parasitology (Ministry of Agriculture, Fisheries and Food, MAFF, 1971).

At the beginning (day 1) and end (day 30) of the trial, the herbage samples were collected from each paddock in the morning in a "double-crossed W shape" transect, every ten steps, close to the soil surface. The composite samples $(c a .1 \mathrm{~kg}$ ) for each paddock were soaked in water for at least 6 $\mathrm{h}$ to loosen the larvae. The forage was removed and dried in a convective oven at $65^{\circ} \mathrm{C}$ for $48 \mathrm{~h}$ to determine the dry matter content. The infective larvae (L3) were obtained from the sediment and identified at the genus level (MAFF, 1971). The results were expressed as the larvae number per $\mathrm{kg}$ of forage DM.

The statistical analysis was performed by means of a two-way ANOVA (Statgraphics Centurion software, version XVI). For the FEC (epg), a splitplot design was employed to estimate the effect of the type of pasture (Pl-C or PP, main plot), endectocide treatment (sub-plot), and the interaction 
between them. The same analysis was also used for the larval genera and live weight gain (LWG) of the lambs. The variables were transformed to their logarithmic values prior to the analysis to comply with homogeneity of variances. However, the results are presented as average values without transformation. For the ILIP analysis, the effects of pasture type and period (sampling day) were evaluated with a factorial arrangement (2 pastures $\mathrm{x} 2$ periods). The paddock was employed as the experimental unit.

\section{Results}

At the start of the experiment, the FEC were low and comparable between pastures, with an average of $c a .80 \mathrm{epg}$. At the end of the study the counts increased, with mean values of $c a .320,283$ and 37 epg for total, Strongylid- and Nematodirustype eggs, respectively. Although no significant effects $(\mathrm{P}>0.05)$ of pasture type were detected, a trend of higher counts was apparent for the herb pasture, especially if the FEC of the non-treated lambs were considered. Hence, the count for total eggs, separated by Strongylid and Nematodirus type, were 444 vs. 519 (total), 384 vs. 447 (Strongylids) and 56 vs. 72 (Nematodirus) for the PP and Pl-C swards of the non-treated lambs. The anthelmintic (ivermectin) treatment was more effective, as the treated lambs exhibited lower counts $(\mathrm{P}<0.01)$ of total nematodes, Strongylidtype and Nematodirus-type eggs, in comparison with the non-treated lambs. No interaction was found between the type of pasture and endectocide treatment (Table 1).

A small number of total larvae was obtained from the feces culture, approaching 0.05 as a fraction of the total FEC. No effect $(\mathrm{P}>0.05)$ of pasture type was found on the larval genera recovered, and a similar pattern was found for anthelmintic treatment, except for the Cooperia larvae that were negatively affected $(\mathrm{P}<0.05)$ by the endectocide. No interaction was apparent $(\mathrm{P}>0.05)$ between the pasture type and antiparasitic treatment neither for the total L3 nor for any larval genera (Table 1).

The L3 identified in the pasture samples comprised the genera Trichostrongylus spp., Ostertagia spp., Chabertia spp. and Cooperia spp. (Table 2). The numbers were lower for the Pl-C compared to the PP sward, with significant differences $(\mathrm{P}<0.05)$ for total L3 and Trichostrongylus L3 and a tendency to decrease for Chabertia and Ostertagia.

Table 1. Effects of pasture type and ivermectin treatment of grazing lambs on fecal egg counts (epg) and larvae obtained from feces cultures at the end of the study.

\begin{tabular}{|c|c|c|c|c|c|c|c|c|}
\hline \multirow{2}{*}{ Variable } & \multicolumn{2}{|c|}{ Pasture type } & \multicolumn{2}{|c|}{ Ivermectin } & \multirow{2}{*}{ SEM } & \multicolumn{3}{|c|}{ P-Value } \\
\hline & PP & $\mathrm{Pl}-\mathrm{C}$ & Yes & No & & Pasture & Ivermectin & Interaction \\
\hline \multicolumn{9}{|c|}{ Fecal egg counts (epg) } \\
\hline Total FEC & 286.78 & 352.78 & 157.62 & 481.94 & 46.04 & 0.359 & 0.001 & 0.922 \\
\hline Strongylids & 253.94 & 312.50 & 148.39 & 418.06 & 42.25 & 0.248 & 0.002 & 0.998 \\
\hline Nematodirus & 32.84 & 40.28 & 9.23 & 63.89 & 8.82 & 0.806 & 0.003 & 0.603 \\
\hline \multicolumn{9}{|c|}{ Larvae from fecal culture } \\
\hline Total larvae & 15.7 & 15.2 & 7.8 & 23 & 4.22 & 0.97 & 0.15 & 0.53 \\
\hline Ostertagia & 12.2 & 8.7 & 5.8 & 15 & 2.85 & 0.68 & 0.18 & 0.65 \\
\hline Trichostrongylus & 2.2 & 1.3 & 1.2 & 2.3 & 0.33 & 0.37 & 0.16 & 0.16 \\
\hline Chabertia & 1.0 & 4.5 & 0.7 & 4.8 & 1.52 & 0.38 & 0.24 & 0.24 \\
\hline Cooperia & 0.3 & 0.7 & 0.2 & 0.8 & 0.12 & 0.42 & 0.04 & 1.0 \\
\hline
\end{tabular}

PP: Permanent pasture, Pl-C: Plantain-chicory mixture, SEM: Standard error of the mean, Interact.: Interaction, FEC: Fecal egg counts, epg: eggs per gram. 
Concerning the effects of pasture type and sampling period (initial and final), it can be seen (Table 3) that throughout the experiment, total L3, Ostertagia spp. and Trichostrongylus spp. larvae increased $(\mathrm{P}<0.05)$. A similar trend $(\mathrm{P}=0.11)$ was observed for Chabertia spp., whereas Cooperia spp. did not change $(\mathrm{P}=0.54)$. Higher numbers of total L3, Trichostrongylus spp. and Chabertia spp. $(\mathrm{P}<0.05)$ were obtained from the $\mathrm{PP}$ pasture in comparison to the $\mathrm{Pl}-\mathrm{C}$ mixture, with a similar tendency $(\mathrm{P}=0.1)$ for Ostertagia spp., but no effect $(\mathrm{P}=0.24)$ was observed for Cooperia spp. However, significant interactions $(\mathrm{P}<0.05)$ were observed between the pasture type and period for total L3 and Trichostrongylus spp. larvae. Specifically, both larval types increased significantly in the second period only for the PP pasture, whereas in the Pl-C mixture, the larval counts were maintained (interactions not shown).
The live weight gain of lambs for the complete experimental period averaged $173 \mathrm{~g} \mathrm{~d}^{-1}$, and no effect $(\mathrm{P}=0.72)$ was detected for the type of pasture, anthelmintic $(\mathrm{P}=0.51)$ treatment, or their interaction $(\mathrm{P}=0.64)$. The average nutritional composition of the pastures throughout the study for the herb (Pl-C) and grass-type (PP) swards were 10.38 and $12.09 \mathrm{MJ} \mathrm{kg}^{-1} \mathrm{DM}$ for metabolizable energy, 214 and $191 \mathrm{~g} \mathrm{~kg}^{-1} \mathrm{DM}$ for crude protein, 348 and 450 $\mathrm{g} \mathrm{kg}^{-1} \mathrm{DM}$ for neutral detergent fiber, 286 and 253 $\mathrm{g} \mathrm{kg}^{-1} \mathrm{DM}$ for acid detergent fiber, and 136 and $86 \mathrm{~g} \mathrm{~kg}^{-1} \mathrm{DM}$ for ash.

\section{Discussion}

The low initial parasite load found in the present study is probably explained by the drenching applied to the experimental lambs previous to weaning and by the low worm burden expected

Table 2. Total infective larvae (L3), separated by genus, recovered from pastures (average number per kg DM) at the end of the study.

\begin{tabular}{lcccc}
\hline \multirow{2}{*}{ Variable } & \multicolumn{2}{c}{ Pasture type } & SEM & P-Value \\
\cline { 2 - 3 } & PP & Pl-Ch & & \\
\hline Total L3 & 279.82 & 77.10 & 50.87 & 0.048 \\
Ostertagia & 151.71 & 59.80 & 39.35 & 0.174 \\
Trichostrongylus & 85.22 & 17.30 & 15.59 & 0.037 \\
Chabertia & 29.48 & 0 & 9.30 & 0.089 \\
Cooperia & 13.41 & 0 & 9.48 & 0.374 \\
\hline
\end{tabular}

PP: Permanent pasture, Pl-C: Plantain-chicory mixture, SEM: Standard error of the mean.

Table 3. Total infective larvae (L3), separated by genus (number per kg DM), obtained from each pasture type in two periods (days 1 and 30 ) and the associated interaction.

\begin{tabular}{|c|c|c|c|c|c|c|c|c|}
\hline & \multicolumn{2}{|c|}{ Pasture type } & \multicolumn{2}{|c|}{ Period } & \multirow[b]{2}{*}{ SEM } & \multicolumn{3}{|c|}{ Significance } \\
\hline & $\mathrm{PP}$ & $\mathrm{Pl}-\mathrm{Ch}$ & 1 & 2 & & Pasture & Period & Interaction \\
\hline Total L3 & 170.9 & 62.8 & 55.2 & 178.5 & 18.48 & 0.019 & 0.010 & 0.034 \\
\hline Ostertagia & 96.4 & 43.6 & 34.3 & 105.8 & 14.16 & 0.099 & 0.036 & 0.205 \\
\hline Trichostrongylus & 48.5 & 19.2 & 16.5 & 51.3 & 5.97 & 0.039 & 0.019 & 0.012 \\
\hline Chabertia & 17.0 & 0 & 2.2 & 14.7 & 3.47 & 0.040 & 0.110 & 0.110 \\
\hline Cooperia & 8.94 & 0 & 2.2 & 6.7 & 3.53 & 0.242 & 0.544 & 0.544 \\
\hline
\end{tabular}

PP: Permanent pasture, Pl-C: Plantain-chicory mixture, SEM: Standard error of the mean. 
in pastures that were sown early in the same year. Therefore, most L3 present in mid-November (at the beginning of the trial) probably developed from the dispersal of eggs from the previous grazing of ewes and their lambs. The subsequent increase in the FEC at the end of the trial was moderate, possibly a consequence of the residual effect of the endectocide applied, as no effect of the forage species was apparent. The results obtained for the effects of type of pasture do not support the main hypothesis, as no effect of pasture type was detected on the FEC. In fact, the epg for the Pl-C treatment was over 20\% higher than that of the PP, although this increase was non-significant. Anthelmintic administration to half the lambs at the beginning of the trial, on the other hand, resulted in a lower increase in total, Strongylid- and Nematodirus-type eggs. A possible explanation for the lack of effect of pasture type or its interaction with anthelmintic application on the total FEC and egg type could be related to the prepatent period of GIN. The prepatent period is the lapse between the infection of an animal by ingestion of L3 and the first egg production by the adult female parasite and it typically takes approximately three weeks (Sievers and Nannig, 2006).

All lambs demonstrated increased GIN loads by the end of the study, as estimated by the FEC. Even the lambs treated with anthelmintic exhibited a higher worm load at the end of the trial, despite the fact that a residual effect of ivermectin has been found up to $10 \mathrm{~d}$ after injection (Borgsteede, 1993). However, the anthelmintic-treated lambs showed a significantly $(\mathrm{P}<0.01)$ lower parasite burden ("low", with $<200$ epg) than the non-treated lambs ("moderate", with $<500$ epg). This included burdens of the genus Nematodirus that, with low counts, produced less $(\mathrm{P}<0.01)$ eggs in the treated ( $c a .10$ epg) than in the non-treated animals (ca. 64 epg). Nematodirus spp., a ubiquitous GIN found in small ruminants, is a common parasite in Southern Chile. An increasing resistance to ivermectin from this genus has been found in sheep (Toro et al., 2014), but this was not the case in our results.
It is important to consider that the egg count expressed as total epg or according to genera, i.e., Strongylid-type eggs (Trichostrongylus, Ostertagia, Cooperia and Chabertia spp.) or Nematodirus-type eggs, only shows a general image of the level of nematode infection. It could be argued that the FEC does not necessarily represent the actual number of worms present, since it is affected by their maturity stage and oviposition capacity. Nonetheless, research suggests that the FEC presents a good correlation with worm counts, particularly for groups of animals in their first year of life (Rattray, 2003). In a recent paper, Laurenson et al. (2016) reported strong correlations (especially after a prepatent period) between worm burden and FEC values across nematode species, supporting the use of the FEC reduction test as a measure of anthelmintic efficacy.

The objective of the culture of feces was to verify the effects of pasture type and endectocide application on the recovery of L3, which in turn depends on the hatchability of GIN eggs and the factors affecting the development of larvae to the L3 stage. According to our results, a small number of L3 (total and different genera) were recovered from the feces culture, and no effects of pasture type or endectocide were apparent. Only Cooperia was negatively affected by the anthelmintic, with an average of less than one L 3 recovered. The mean number of total L3 recovered represent $c a$. 0.05 of the total epg value for each treatment. It is possible that the lapse of the protocol used, particularly in the final extracting process, could have been insufficient to obtain more L3, even though three replicates were performed per group. It is also possible that some L1 or L2 did not survive the period trapped inside the feces. Uncertainties are also associated with the composition of feces and the moisture and temperature of the culture process, among other issues (Roeber and Khan, 2014), since ideal conditions vary for different species of nematodes. Conversely, Jørgensen et al. (1998) proposed that part of the hatching ability and survival of infective larvae depends on immune host factors that operate directly on 
the eggs before they are expelled, though this hypothesis should be further studied. Roeber and Khan (2014) suggested that the results of larvae culture are useful to evaluate the species present rather than to quantify them. Several conditions can affect the process of obtaining L3 from feces culture, e.g., naturally low fecundity that results in low numbers of eggs, low fertility or hatchability, low viability of intermediate larval stages and adverse conditions in the culture technique. These factors could explain the results obtained in our study, where the quantification did not follow any pattern related to pasture type or anthelmintic treatment (except for Cooperia). The relatively higher number of Ostertagia L3 obtained from the fecal cultures in our study could be related to the shorter prepatent period and high resistance to benzimidazoles of this genus (Bartley et al., 2004) compared to other genera. Nematodirus L3 were not in the culture, because the larvae develop to L3 inside the egg and hatch after being ingested by the host. For a more detailed review on the limitations of larval culture techniques, the reader is referred to Roeber and Khan (2014).

The number of L3 in herbage provides important information concerning the risk of uptake of larvae by grazing animals. We assumed that the L3 load in the Pl-C pasture would be lower in comparison with the PP pasture but it was also expected that the number would increase over time. Although, on average, both hypotheses are supported by our results, some interactions are evident, as initial counts were low and comparable between pasture types, though they tended to increase at the end of the study only for the PP pasture.

A lower recovery of larvae from pastures has been found for chicory compared to grass-clover swards (Kidane et al., 2010). This could be related to the presence of secondary bioactive metabolites, such as sesquiterpene lactones among other compounds in chicory, that could affect motility and viability of GIN larvae (Hoste et al., 2006). It has been noted that plantains contain several bioactive metabolites (not determined in this study), nota- bly, the iridoid glycosides aucubin and catalpol and condensed tannins (Ramírez-Restrepo and Barry, 2005). Although there is interest in the anthelmintic properties of plantains, the evidence supporting a direct effect is scarce (Sievers and Nannig, 2006). However, important antimicrobial and anti-inflammatory effects have been found in iridoid glycosides from plantains, and these effects are even stronger in their degradation products (Viljoen et al., 2012). It could be hypothesized that bioactive metabolites from herbs (chicory and/or plantain) or their derivatives excreted in feces affected the GIN eggs (lower hatchability) or the intermediary stage larvae (L1, L2) in the fecal environment, impairing migration or nutrition and affecting parasite survival.

Sward architecture and plant surface structures could play significant roles as well. The spatial distribution and density of plants could be involved in the probability of L3 migrating in the plant profile. The plants in the Pl-C sward were more erect and had a lower density than in the PP, and this could have been an obstacle to larval migration and survival. With respect to plant structures, Marley et al. (2006) found a significantly lower recovery of GIN L3 from chicory compared to ryegrass swards; although many factors could be involved, their results could be partially explained by the physical barrier represented by the presence of trichomes in chicory leaves that interfere with larval migration. Glandular trichomes act as metabolic factories in different plant organs where in the case of chicory and other members of the Asteraceae family, sesquiterpene lactones are produced and secreted to a subcuticular storage space at the apex of trichomes or excreted to the plant surface (Göpfert et al., 2005). These terpenoids play an important role as deterrents to herbivory and are toxic to pathogens; therefore, they could also represent a chemical repellent to L3, restraining vertical movement.

A positive effect of the herbs sward and the endectocide application on the live weight gain of weaned lambs was hypothesized in the present 
study, and an interaction was expected in the form of a lower gain for lambs in the PP without drenching, since no protection from GIN would be present either from the anthelmintic or the bioactive metabolites expected in the Pl-C forage. However, this was not supported by our findings, as lambs from all the treatments had similar gains $(\mathrm{P}>0.05)$ of $173 \mathrm{~g} \mathrm{~d}^{-1}$, on average. The lack of effects may be explained by the relative low to moderate worm burden estimated from the FEC ( $<400$ epg) at the end of the trial, although the epg increased through the experimental period. Both pastures had good nutritional quality, i.e., sufficient protein and other nutrients that could have exerted a positive interaction with immunity development against GIN. There is evidence that during the early phases of acquiring immunity in the 2-3-month-old lambs, intake and productivity can be severely affected and a positive effect can be expected of an enhanced nutrient supply (Sykes, 2010). Immunity acts through a number of mechanisms, resulting in the rejection of incoming infective larvae, reduction of nematodes, impairment of worm development and fecundity and expulsion of adult nematodes (Athanasiadou et al., 2008). Kidane et al, (2010) found a greater live weight gain of lambs grazing on chicory compared with lambs grazing on ryegrass-clover. In another study, lambs from undrenched ewes grazing on chicory gained more live weight in comparison to lambs from undrenched ewes grazing on grass, but for lambs from drenched ewes, gains were similar between the swards. That study concluded that the growth of young, parasitized lambs is not penalized as a result of parasitism when grazing on chicory (Athanasiadou et al., 2007). Plantain, besides its high nutritional quality, has resulted in lower egg output of parasitic nematodes in calves (Sievers and Nannig, 2006) and presents distinct pharmacological value through antioxidant, anti-inflammatory and wound-healing activities from bioactive compounds such as phenylpropanoid glycosides, iridoids, triterpenes, flavonoids and phenolic acids (Goncalves and Romano, 2016). Thus, parasitized animals could maintain more effective resistance to GIN as a result of a reinforced immune system or a better protected gastrointestinal tract or through direct anthelmintic activity following the consumption of bioactive forages (Athanasiadou et al., 2008). On the other hand, secondary bioactive metabolites can also adversely affect the parasitized herbivores through anti-nutritional factors resulting in lower dry matter intake or toxic effects. Therefore, the concentration of specific metabolites and amounts ingested represent a trade-off between positive and detrimental effects.

It has been proposed that in late spring and early summer, mixtures of herbs (plantain or chicory) and clover are better options than ryegrassclover mixtures for finishing lambs in temperate regions (Somasiri et al., 2016). In our study, the combined effects of the factors discussed earlier did not result in better gains of lambs grazing on the mixed-herbs sward. The climatic conditions were beneficial for both types of swards in our experiment, with some precipitation and mild temperatures (results not shown) that, in addition to soil residual moisture, were adequate for the growth of ryegrass and other grasses in the first three weeks of the experiment. By the fourth week, the lack of rainfall resulted in a reduction of forage growth, particularly for the PP pastures; this precluded the extension of the study.

In conclusion, no effects were detected for the type of sward (chicory-plantain or permanent grass-based) on the FEC, in terms of the total, Strongylid- or Nematodirus-type eggs. Endectocide application, on the other hand, resulted in a reduction of the total, Strongylid-, and Nematodirustype eggs. The total L3, as well as the larvae of the genera Ostertagia, Trichostrongylus and Chabertia obtained from fecal cultures, were not affected by pasture type or anthelmintic treatment, although Cooperia was reduced. The number of L3 recovered from forage at the end of the experiment was significantly lower for the chicory-plantain mixture compared to the permanent pasture, leading to a lower infective risk for the herbs sward. 
In contrast to other works, the chicory-plantain mixture did not lead to higher live weight gains in finishing lambs in comparison to the grass-based sward. It is possible that prolonging the finishing period further into the summer could result in more evident effects in favor of the herbs sward, but this was not possible in our study.

\section{Acknowledgements}

This work was supported by a grant from FONDECYT, Project 1141043.

The authors declare that there is no conflict of interest regarding the publication of this paper.

\section{Resumen}

D. Alomar, P. Ruiz, O. Balocchi, G. Valenzuela, y D. Goic. 2018. Engorda de corderos en una mezcla de achicoria-plantago o una pradera basada en gramíneas de clima templado: ganancia de peso y parasitismo gastrointestinal. Cien. Inv. Agr. 45(1): 11-20. Variedades mejoradas de plantago (P. lanceolata L.) y achicoria (Cichorium intybus L.) son interesantes para engordar corderos y pueden protegerlos del parasitismo interno por sus metabolitos secundarios. Este estudio comparó la ganancia de peso y carga parasitaria de corderos destetados terminados en una mezcla de plantago-achicoria (Pl-C) o una pradera permanente basada en gramíneas (PP), tratados o no con un endectocida. Setenta y dos corderos con peso promedio de $32 \mathrm{~kg}$ se distribuyeron en tres potrerillos por cada tipo de pradera, por 30 días desde mediados de noviembre. La mitad de los corderos se trató inicialmente con ivermectina. Se evaluó recuento fecal de huevos (FEC), géneros larvarios y recuento de larvas L3 en las praderas. La carga de FEC inicial (ca. $80 \mathrm{hpg}$ ) o final (322 hpg) fue similar $(\mathrm{P}>0.05)$ entre praderas. El tratamiento con ivermectina logró menor $(\mathrm{P}<0.01)$ recuento total (482 vs. 158 hpg), huevos tipo estrongílidos (418 vs. 148 epg) y Nematodirus (64 vs. 9 epg). Las cargas parasitarias finales estimadas fueron bajas $(<400 \mathrm{hpg})$. No hubo efecto del tipo de pradera, antihelmíntico o su interacción, para el número de larvas obtenidas del cultivo de fecas, excepto para Cooperia que disminuyó con la ivermectina. Las larvas L3 en la pradera aumentaron $(\mathrm{P}<0.05)$

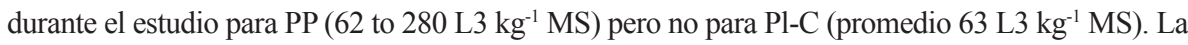
ganancia de peso fue similar $(\mathrm{P}>0.05)$ entre tratamientos (promedio $\left.173 \mathrm{~g} \mathrm{~d}^{-1}\right)$ reflejando una calidad nutricional adecuada de ambas praderas y un parasitismo moderado.

Palabras clave: Hierbas forrajeras, larvas infectantes, nemátodos gastrointestinales, ovinos.

\section{References}

Athanasiadou, S., D. Gray, D. Younie, O. Tzamaloukas, F. Jackson, and I. Kyriazakis. 2007. The use of chicory for parasite control in organic ewes and their lambs. Parasitology 134:299-307.

Athanasiadou, S., J. Houdijk, and I. Kyriazakis. 2008. Exploiting synergisms and interactions in the nutritional approaches to parasite control in sheep production systems. Small Ruminant Res 76:2-11.

Bartley, D., F. Jackson, E. Jackson, and N. Sargison. 2004. Characterisation of two triple resistant field isolates of Teladorsagia from Scottish lowland sheep farms. Vet. Parasitol. 123:189-199.

Borgsteede, F.H.M. 1993. The efficacy and persistent anthelmintic effect of ivermectin in sheep. Vet. Parasitol. 50:117-124.

Githiori, J.B., S. Athanasiadou, and S.M. Thamsborg. 2006. Use of plants in novel approaches for control of gastrointestinal helminths in livestock with emphasis on small ruminants. Vet. Parasitol. 139:308-320.

Goncalves, S., and A. Romano. 2016. The medicinal potential of plants from the genus 
Plantago (Plantaginaceae). Ind Crops Prod 83:213-226.

Göpfert, J.C., N. Heil, J. Conrad, and O. Spring. 2005. Cytological development and sesquiterpene lactone secretion in capitate glandular trichomes of sunflower. Plant Biology 7:148-155.

Hoste, H, F. Jackson, S. Athanasiadou, S.M. Thamsborg, and S.O. Hoskin. 2006. The effects of tannin-rich plants on parasitic nematodes in ruminants. Trends Parasitol. 22:253-261.

Jørgensen, L., D. Leathwick, W. Charleston, P. Godfrey, A. Vlassoff, and I. Sutherland. 1998. Variation between hosts in the developmental success of the free-living stages of trichostrongyle infections of sheep. Int. J. Parasitol. 28:1347-1352.

Kidane, A., J.G.M. Houdijk, S. Athanasiadou, B.J. Tolkamp, and I. Kyriazakis. 2010. Effects of maternal protein nutrition and subsequent grazing on chicory (Cichorium intybus) on parasitism and performance of lambs. Journal of Animal Science 88:1513-1521.

Laurenson, Y.C.S.M., L.P. Kahn, S.C. Bishop, and I. Kyriazakis. 2016. Which is the best phenotypic trait for use in a targeted selective treatment strategy for growing lambs in temperate climates? Vet. Parasitol. 226:174-188.

Marley, C.L., R. Cook, J. Barrett, R. Keatinge, and N.H. Lampkin. 2006. The effects of birdsfoot trefoil (Lotus corniculatus) and chicory (Cichorium intybus) when compared with perennial ryegrass (Lolium perenne) on ovine gastrointestinal parasite development, survival and migration. Vet Parasitol. 138:280-290.

Ministry of Agriculture, Fisheries and Food (MAFF). 1971. Manual of veterinary parasitological laboratory techniques. Technical Bulletin 18, London, UK.

Molan, A.L., A.J. Duncan, T.N. Barry, and W.C. McNabb. 2003. Effects of condensed tannins and crude sesquiterpene lactones extracted from chicory on the motility of larvae of deer lungworm and gastrointestinal nematodes. Parasitol. Int. 52:209-218.

Peña-Espinoza, M., U. Boas, A.R. Williams, S.M. Thamsborg, H.T. Simonsen, and H.L. Enemark. 2015. Sesquiterpene lactone containing extracts from two cultivars of forage chicory (Cichorium intybus) show distinctive chemical profiles and in vitro activity against Ostertagia ostertagi. Int J Parasitol Drugs Drug Resist 5:91-200.

Ramírez-Restrepo, C.A., and T.N. Barry. 2005. Alternative temperate forages containing secondary compounds for improving sustainable productivity in grazing ruminants. Anim. Feed Sci. Technol. 120:179-201.

Rattray, P.V. 2003. Helminth parasites in the New Zealand Meat \& Wool Pastoral Industries: A review of current issues. Final report. Meat \& Wool Innovation Ltd., New Zealand.

Roeber, F., and L. Khan. 2014. The specific diagnosis of gastrointestinal nematode infections in livestock: Larval culture technique, its limitations and alternative DNA-based approaches. Vet Parasitol. 205:619-628.

Sievers, G., and S. Nannig. 2006. Effect of the supplementary feeding with Plantago lanceolata on the egg output of gastrointestinal nematodes in calves. Archivos de Medicina Veterinaria 38:233-238.

Somasiri, S.C., P.R. Kenyon, P.D. Kemp, P.C.H. Morel, and S.T. Morris. 2016. Mixtures of clovers with plantain and chicory improve lamb production performance compared to a ryegrass-white clover sward in the late spring and early summer period. Grass Forage Sci 71:270-280.

Sykes, A. 2010. Host immune responses to nematodes: benefit or cost? Implications for future development of sustainable methods of control. Revista Brasileira de Zootecnia 39:376-382.

Toro, A., L. Rubilar, C. Palma, and R. Pérez. 2014. Anthelmintic resistance of gastrointestinal nematode in sheep treated with ivermectin and fenbendazole. Archivos de Medicina Veterinaria 46:247-252.

Viljoen, A., N. Mncwangi, and I. Vermaak. 2012. Anti-inflammatory iridoids of botanical origin. Curr. Med. Chem. 19:2104-2127.

Waller, P., and S.M. Thamsborg. 2004. Nematode control in 'green' ruminant production systems. Trends Parasitol. 20:493-497.

Yoshihara, E., A.P. Minho, V. Dutra, S.T. Cardim, and M.H. Yamamura. 2015. Ultrastructural changes in the Haemonchus contortus cuticle exposed to Acacia mearnsii extract. Semina- Ciências Agrárias 36:3763-3768. 